\title{
水中養生および恒温度養生中におけるセメントモルタルの 亀裂発生挙動に関する研究
}

$\mathrm{AE}$ 法を用いたセメント系材料の亀裂挙動および破壊挙動の測定と解析 その 1

$\begin{array}{lllll}\text { 正会員 } & \text { 棚 } & \text { 野 } & \text { 博 } & \text { 之* } \\ \text { 正会貝 } & \text { 重 } & \text { 倉 } & \text { 祐 } & \text { 光** } \\ \text { 正会員 } & \text { 槻 } & \text { 山 } & \text { 興 } & \text { 一*** }\end{array}$

\section{I. 序}

セメント系材料の養生方法は大別して 1) 水中養生, 2）恒温養生，3）蒸気養生やオートクレープ養生等の特 殊養生，の3つに分けられる。このうち特殊養生の養生 条件は，材料に要求される各種の特性值を満たすために 異なる。一方水中養生および恒温養生方法は JIS ゃ JASS 等によって定められているため, 実験室レベルの 養生はこれらの規定に準じて行われるのが一般的であ る。しかしセメント系材料の内部組織が養生中どのよう に変化するかは，いまだ明らかでない。また，膨張亀裂 および収縮亀裂の発生挙動については, 材料表層部に発 生する巨視（ミリオーダ）レベルの亀裂が測定の主体と なっている。

従来モルタルやコンクリート等のセメント系材料の乾 燥収縮に関する研究は 1）収縮機構 ${ }^{* 1-3} ， 2 ）$ 収縮率推定 計算式 ${ }^{* 4,5} 3$ ）乾燥収縮が拘束断面, 内部応力, プレス トレスおよび構造物の変形に及ぼす影響 ${ }^{* 6-8}$ ，の 3 つに 関するものがその大部分である。収縮機構に関しては, 毛細管張力理論, 表面吸着理論, 層間水理論等が上げら れているが，いまだ明確な理論は確立されていない。ま た, 収縮率推定計算式は, 環境湿度, 乾燥期間, 部材寸 法, 配合率および拘束度等を要因とし，これら要因の取 り扱は極めて複雑である。建築学会および土木学会等で はこれらを考虑して独自の簡易式を提案している。しか し，これら簡易式によって算出された収縮率は養生条件 ならびに施工方法等の影響を受け，信頼性において必ず しも高くない。

乾燥収縮によって起こる最も顕著な現象は，亀裂の発 生および進展である。通常供試体拘束力が作用しない場 合，供試体における収縮の進行は乾燥にさらされている 表面から起こり, 次第に内部に及んで行く。その結果,

* 東京理科大学 大学院生 $\cdot$ 工修

** 東京理科大学 教授.工博

*** 小野田セメント中央研究所 主席研究員 · 理博 (昭和 61 年 6 月 9 日原稿受理)
体積変化率の一様でない部分に発生する内部応力が収縮 亀裂を発生させ，また拘束力が作用する場合は，さらに 内部応力が高まり収縮亀裂の長さ, 幅および数は増大す ると考えられている。

収縮亀裂は材料表層部に表れる巨視レベルなものと， 材料内部に表れる微視（100ミクロンオーダ）レベル以 下のものとに分けられる。巨視レベルの収縮亀裂はク ラックゲージ等を用いた目視による測定が可能なため, これまで数多くの研究成果が発表されている。一方, 微 視レベルの収縮亀裂（以後微視亀裂亡略す）は寸法が極 めて小さく,かつその大多数は材料内部で発生するため, 従来の技術で亀裂挙動（発生位置, 発生量および発生時 期）を測定することは極めて困難であった。したがって， これまで微視亀裂の挙動を実験によって明らかにした例 は極めて少ない。しかし, 微視亀裂が材料の勒性化を妨 げることは明らかであり, また破壊力学において従来提 案されている各種の破壊理論（微視領域）はこれまで実 験による実証がなされいなかった。したがって，建築や 土木等の材料力学および破壊力学の面からも微視亀裂挙 動を明らかにしてゆくことはこれからの重要研究課題で ある。

近年金属や岩石の分野では物質破壊に際して放出され る高周波弾性波を電気信号に変換し，この信号と微視的 破壊とを対応させる Acoustic Emission (AE) 法の研 究*9,10,11がなされおり，実際に各種方面で利用されてい る。現在では金属や岩石だけでなく、コンクリート等の 多孔質材料に対しても $\mathrm{AE}$ の利用研究 ${ }^{* 12,19}$ が数多く発表 されるようになった。

$\mathrm{AE}$ の解析方法は大別して 1) イベントを中心とした 解析方法, 2) $\mathrm{AE}$ 位置標定, 3) 波形解析 ${ }^{* 20-23}$ の 3 種類 がある。 $\mathrm{AE}$ イベントカウントや $\mathrm{AE}$ エネルギーを特性 パラメータとするイベント解析は一般によく用いられて いる方法で, 自動計測が容易, かつデータがリアルタイ 么に得られる利点をもっている。 $\mathrm{AE}$ 位置標定は $\mathrm{AE}$ 波 の発生位置を各 $\mathrm{AE}$ センサーの到達時間差より求める 
手法である。波形解析には原波形解析と周波数解析の 2 種類がある。原波形解析は, $\mathrm{AE}$ センサーで検出された 波形をもとに, $\mathrm{AE}$ 波伝播特性を中心とした変換を行い, 発生 $\mathrm{AE}$ パルスへの帰還を目的とした手法である。よっ てセンサー特性，供試体の寸法，形状および $\mathrm{AE}$ 波伝 播特性等の影響すべてが除去された情報を得ることが可 能で, 個々の微視破壊を明確に把握する意味で, $\mathrm{AE}$ 解 析における重要な手法である。しかし，セメント系材料 のように多数の $\mathrm{AE}$ 波を発生する物に対し行われた例 は，著者の知る範囲では極めて少ない。一方，周波数解 析は検出波をスペクトラム変換し，その結果得られた $\mathrm{AE}$ パワースペクトラムの特性周波数をもとに識別を行 い，破壊機構との関係を求めることを目的とした手法で ある。従来周波数解析を行う場合, 検出波を個々に解析 していたため，原波形解析程ではないが，解析には時間 を要した。しかし，1981 年に自動 $\mathrm{AE}$ 周波数解析装置 が開発され，セメント系材料に対する周波数解析も実現 可能となった。

本報における $\mathrm{AE}$ 解析はイベントを中心とした解析 と位置標定解析にとどまっている。しかし，第 2 報では 養生後の破壊勒性試験（弾塑性破壊勒性 JIC 試験*25, 詳細については第 2 報で述べる）における破壊過程（応 力一ひずみ）と，この時発生する微視亀裂との関係を明 らかにするため，上記自動 $\mathrm{AE}$ 周波数解析装置を用い て周波数解析を行っている。

\section{II. 研究目的}

筆者らは,これまでセメント系材料の破壊挙動の評価 方法として $\mathrm{AE}$ を用い，1）セメント系材料に対する $\mathrm{AE}$ の適用性ならびにその試験精度，2）供試体の変形 挙動と微視亀裂挙動との対応関係を研究してきた。また, 実験内容は破壊勒性試験時の挙動を中心とした, 水セメ ント比（以後 W/C と略す）別の比較検討であった。し かしセメント系材料の場合, 養生方法および条件によっ て破壊挙動が大きく異なることは，周知の事実である。 養生の違いによって破壊挙動が変化する過程には，水和 率および水和速度の増娍，水和物の生成形態ならびに膨 張および収縮による潜在微視亀裂の発生が大きな原因と して考えられる。このうち膨張および収縮による潜在微 視亀裂の発生理論については序の部分でも述べたように 2, 3 の仮説が上げられている。しかし実験によって発 生挙動を的確に把握した報告は極めて少ない。

本研究は, セメント系材料の水中養生および恒温養生

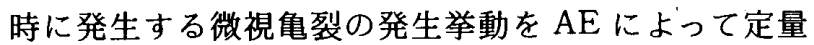
的 (発生時期, 発生場所, 亀裂数) に測定し, 水中養生 中における 1) 微視亀裂 (膨張および収縮亀裂) 発生の 有無を確認。2）微視亀裂が発生する場合, 微視亀裂数 および発生時期と長さ変化率との関係を明らかにする。 また, 恒温養生中における 1）収縮亀裂の発生挙動と供
試体の長さ変化率および重量変化率との関係を明らかに する。2）W/C，骨材の有無ならびに骨材粒径が収縮亀 裂の発生挙動に対しどのような影響を及ぼすかを明らか にする。以上の 4 点を目的として行った。

\section{III. 実験方法}

\section{1 実験概要}

本研究は, 特に乾燥収縮亀裂の発生挙動を明確にする 為, 水中養生, 恒温養生の 2 水準に分けて実験を行った。

1.1 第 1 実験：水中養生セメントモルタルの養生中 における微視亀裂発生有無の確認，亀裂発生源の位置標 定，ならびに微視亀裂挙動とひずみ度 (長さ変化率) と の関係を明らかにすることを目的とした。亀裂の位置評 定にはFig.1 (a)，（b) に示した 2 種類（A1：切り欠 け無し，A 2：切り久け有り）のセメントモルタル供試 体を用いた。また，セメントモルタルは普通ポルトラン ドセメント，豊浦標準砂を用い $\mathrm{W} / \mathrm{C}=60 \%$, 砂セメン 卜重量比 (以後 $\mathrm{S}: \mathrm{C}$ と略す) $=2: 1$ に調合したもので ある。なお，A 1，A 2 の 2 種類の供試体を用いた理由 は以下のとおりである。

第 2 報で行う破壊勒性試験には参考文献 25 において A 2 型の供試体を用いることが明示されている。第 2 報 では養生中および破壊勒性試験時に発生する微視龟裂の 関係を求めているが，この際供試体寸法ならびに形状に よる差を緩和するためである。また，A 1 型の供試体を 併用したのは，切り久けの有無で微視亀裂発生挙動によ゙

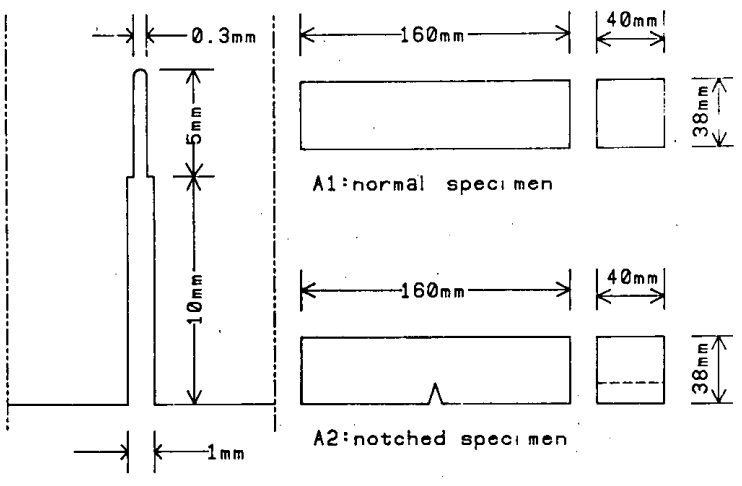

Fig. 1 Specimen size

Table 1 Factors and Classes of Second Experiment

\begin{tabular}{|c|c|c|c|}
\hline & $\begin{array}{l}\text { Cement } \\
\text { Paste }\end{array}$ & $\begin{array}{l}\text { Cemen } \\
\text { (S: }\end{array}$ & $\begin{array}{l}\text { Mortar } \\
=2: 1)\end{array}$ \\
\hline gregate & & Standard Sand & River Sand \\
\hline
\end{tabular}

Table 2 Quality of Standard and River Sand

\begin{tabular}{l|c|c}
\hline & Standard Sand & River Sand \\
\hline Maximum size & $0.6 \mathrm{~mm}$ & $2.4 \mathrm{~mm}$ \\
\hline Minimum size & $0.3 \mathrm{~mm}$ & $1.2 \mathrm{~mm}$ \\
\hline $\begin{array}{l}\text { Percentage of } \\
\text { water absorption }\end{array}$ & $0.74 \%$ & $2.21 \%$ \\
\hline $\begin{array}{l}\text { Surface-dry } \\
\text { specific gravity }\end{array}$ & 2.59 & 2.60 \\
\hline $\begin{array}{l}\text { Ovendry specific } \\
\text { gravity }\end{array}$ & 2.57 & 2.54 \\
\hline
\end{tabular}


のような差が生じるかを明らかにし，かつ JIS 等に規 定されいる試験を用いた場合との差を明らかにするため である。

1.2 第 2 実験：セメントモルタルおよびセメント ペーストにおける収縮亀裂の発生挙動と長さ変化率およ び重量変化率との対応関係を明らかにすることを目的と し, W/C, 骨材の有無および骨材粒径による比較検討 を行った。養生は打設後 1 週間水中養生 $\left(21 \pm 2^{\circ} \mathrm{C}\right)$ を 行い, その後恒温養生 (温度 $21 \pm 3^{\circ} \mathrm{C}$, 湿度 $45 \pm 5 \%$ ) した。供試体は A 2 型のものを用いた。なお W/C およ び使用骨材の各水準を Table 1 に, 骨材の物性を Table 2 に示した。

\section{2 供試体作製方法}

セメントモルタルはJIS R 5201 に準じて（モルタル ミキサー使用）混練したものを用いた。セメントペース トはモルタルミキサーに水を投入後，摜はんしながら 1 分間でセメントを投入, その後 3 分間練り混ぜたものを 用いた。打設用型わくは，A 1 については $4 \times 4 \times 16 \mathrm{~cm}$ 3 連型鋼製型わくに $0.2 \times 4 \times 16 \mathrm{~cm}$ のアクリル板を側 面に装着したものを用い，A 2 はさらに A 1 用型わくに 厚さ $0.3 \mathrm{~mm}$, 長さ $12 \mathrm{~mm}$ のカーボンブレードを取り付 けたものを用いた。(Fig.2) なお, カーボンブレード をあらかじめ取り付けておいたのは，1）セメントモル タルおよびセメントペースト硬化後深さ $15 \mathrm{~mm}$ の切り 欠けを入れる作業が非常に困難かつ時間がかかる，2） 硬化後長時間かけて切り久けを入れた場合，作業中にか かる過度な応力によって供試体内部に多数の応力龟裂が 発生する（予備実験で確認）ためである。以下に，供試 体作製手順を記す。

1) JIS R 5201 に準じて, セメントモルタルおよび セメントペーストを型わくに打設する。
2) 約 7 時間後，A 1 はへら等を用いて表面を平滑に する。A 2 は切り欠け幅を広げないよう打設面垂直方 向にカーボンブレードを抜き取り，その後表面を平滑 にする。

3）打設後 24 時間で脱型し，A 2 については水槽内 (乾燥防止のため) で残り $3 \mathrm{~mm}$ の切り欠けを入れる。 4） $21 \pm 2^{\circ} \mathrm{C}$ の水槽内で水中養生する。

3 測定方法

3.1 第 1 実験：水中養生中の A 1, A 2 両供試体に ついて長さ変化率， $\mathrm{AE}$ イベントカウントおよび $\mathrm{AE}$ 発 生源位置（位置評定）を Fig. 3 に示すシステムを用い て測定した。長さ変化率については供試体作成時に埋め 込んだ防水型ストレインゲージによって測定した。また， 使用する $\mathrm{AE}$ センサーは周波数解析の観点から広帯域 でしかも特性周波数に共振の少ないものが理想的である が，反面このようなセンサーは感度が低いのが欠点であ る。セメントモルタルおよびセメントペースト等の多孔 質材料では伝播中の $\mathrm{AE}$ 波がかなり減衰すると予測さ れるため，感度の高いセンサーが必要となる。したがっ て，本研究においては検出感度を最優先させ， $100 \mathrm{KHz}$ 特性共振周波数をもつセンサーを用い，瞬間接着肪で供 試体側面に取り付けた。トータルゲインは $70 \mathrm{~dB}$ で行 い, 増幅された信号は 8 段階 $(0.2,0.4,0.6,0.8,1.0$, $1.2,1.4,1.6 \mathrm{~V})$ にあらかじめ設定したしきい值に従っ て分割され、 1 秒間隔の累積イベント数として出力され る。

なお，測定は材令 4 週より開始した。

3.2 第 2 実験：恒温養生中の $\mathrm{AE}$ ，長さ変化率およ び重量変化率を測定するため，Fig. 4 に示す測定システ 么を用いた。 $\mathrm{AE}$ の仕様および解析方法は第 1 実験と同 様である。なお，長さ変化率は測定分解能 $1 \mu \mathrm{m}$ のダイ
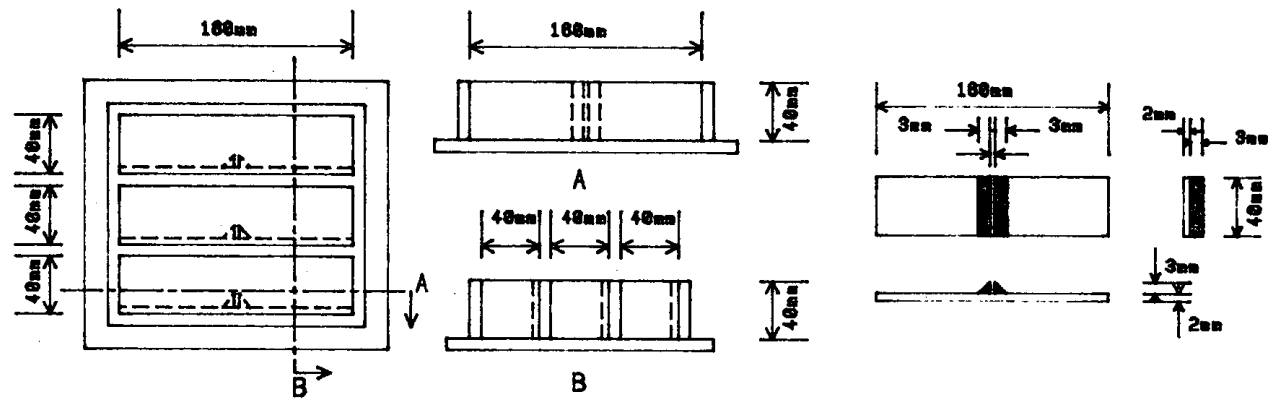

Fig. 2 Formwork size

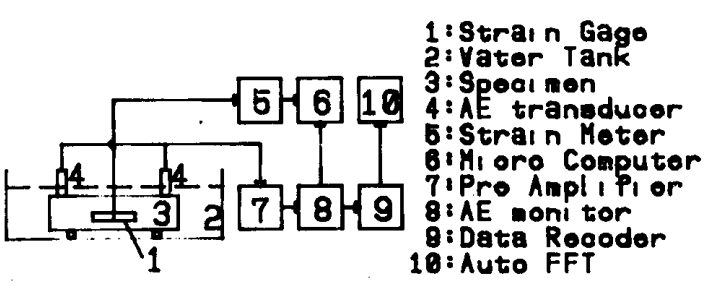

Fig. 3 Measurement system of First experiment

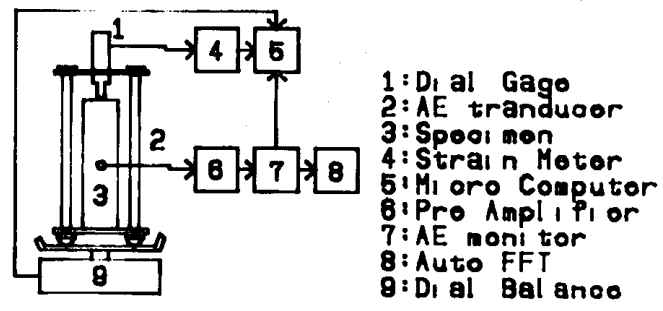

Fig. 4 Measurement system of Second experiment 
ヤルゲージにより, 重量変化率は評量感度 $0.01 \mathrm{~g}$ の直 示電子天科により測定した。

\section{4 解析方法}

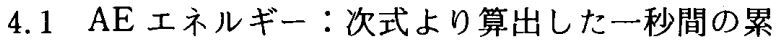
積值 $\left(V_{0-p^{2}}\right)$

$$
\begin{aligned}
& \mathrm{AE} \text { エネルギー } \\
& \quad=n 1\left[\frac{V_{1}+V_{2}}{2}\right]^{2}+n 2\left[\frac{V_{2}+V_{3}}{2}\right]^{2}+\cdots+n 8\left[\frac{V_{8}+2}{2}\right]^{2}
\end{aligned}
$$

$n i:$ 各しきいレベルで発生した

$\mathrm{AE}$ イベントカウント

$V i$ : 各しきいレベルの設定電圧 $(\mathrm{V})$

4. $2 \mathrm{AE}$ イベントエネルギー：1 イベント当たりの 平均 $\mathrm{AE}$ エネルギー $\left(V_{0-p^{2}}\right)$

4. $3 \mathrm{AE}$ 位置標定：供試体長手方向 1 次元の位置標 定とした。なお，クラッキングモニタ一の測定時間分解 能が $0.5 \mu \mathrm{sec}$, セメントモルタル中の弾性波伝播速度 が 3 4 km/sec, さらに供試体厚さが約 $4 \mathrm{~cm}$ であるた め, 標定誤差は $2 \sim 3 \mathrm{~mm}$ 生じる。以下に位置標定計算 を示す。

$$
X=\frac{\left(T_{1}-T_{2}\right) \cdot V_{t}+X_{1}+X_{2}}{2}
$$

$$
X: \mathrm{AE} \text { 発生源位置 }
$$

$X_{1}, X_{2}: \mathrm{AE}$ センサー 1 および 2 の位置

$T_{1}, T_{2}: \mathrm{AE}$ センサー 1 および 2 の検出時間

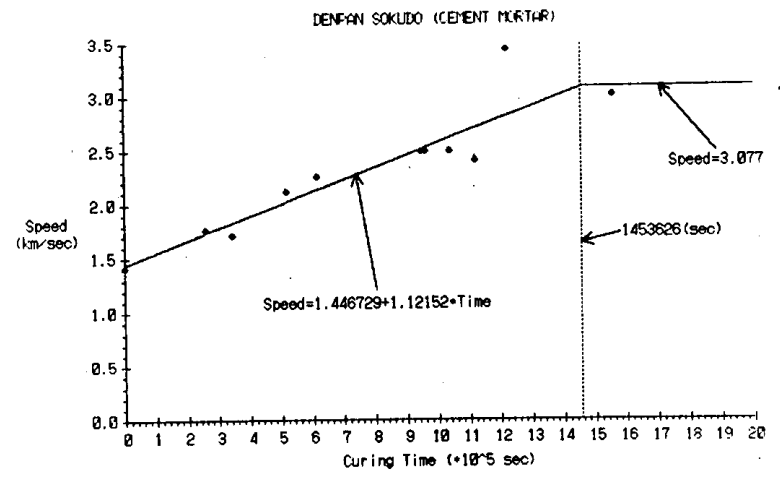

Fig. 5 Curing Time-AE Speed

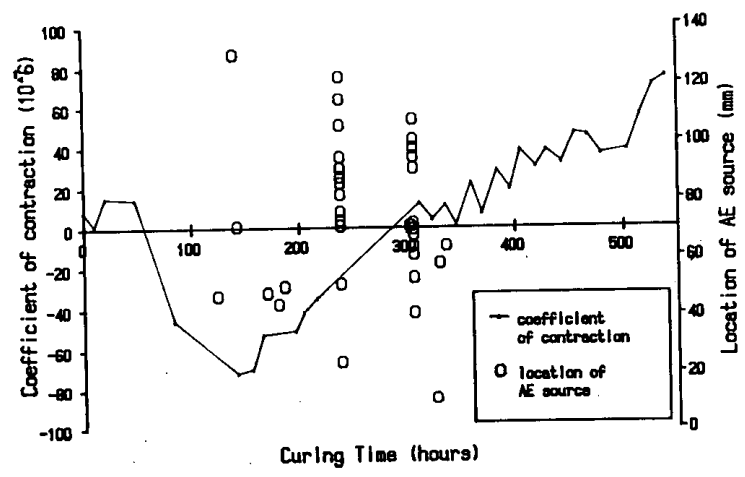

Fig. 6(a) Curing Tim-Coefficient of contraction, Location of $\mathrm{AE}$ source (noram specimen : $\mathrm{A} 1$ )
$V_{t}:$ 供試体中の高周波弾性波速度（水中養生 時においては試験開始および終了時に ファンクションジェネレータより 5 $\mu \mathrm{sec}(100 \mathrm{~Hz})$ の短形パルスを既定位 置より出力して求めた実測平均值。恒温 養生時においては恒温養生開始と共に $\mathrm{AE}$ 波伝播速度は急激に増大する。よっ て，別に用意した A 2 供試体を用い水 中養生と同様の方法で経時的に測定し， その結果を 2 直線近似 (Fig. 5) して, $T_{1}, T_{2}$ ごとに算出した）

\section{N. 実験結果および考察}

1 水中養生中におけるセメントモルタルの長さ変化 および微視亀裂発生挙動：供試体A $1, \mathrm{~A} 2$ 水中養生中 の長さ変化率および 1 次元 $\mathrm{AE}$ 位置標定結果を Fig. 6 (a)，(b) に示した。従来，水中養生中のコンクリート

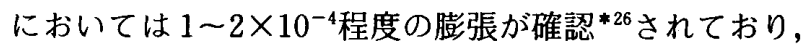
本実験においても経過時間と共に一時若干の収縮現象は 認められるものの, 測定開始後約 550 時間目には供試体 形状にかかわらず A 1 ，A 2 とも $0.7 \times 10^{-4}$ 程度の膨張 を示している。一般に，セメント系材料の膨張は上記し たように，収縮率と比較して極めて小さいため，膨張亀 裂は発生しないと考えられてきた。しかし，Fig.6から は亀裂の発生が認められ，従来の考え方とは明らかに異 なる。このような相違は, 第 1 に亀裂の寸法レベルが異 なっていること，第 2 は膨張の原因が異なること，の 2 点に起因している。

従来考えられていた膨張亀裂は，収縮亀裂と同様セメ ント系材料の表層部に発生し, 肉眼で認識可能な巨視亀 裂を指している。一方，本実験で確認された膨張亀裂は， 水和生成物間において発生する微視亀裂をも含めて指し ている。第 2 の相違点については以下にその内容を示す。

セメント系材料の膨張は一般にエトリンガイト等の膨 張性水和物の生成によって生ずると考えられており，工 トリンガイトの生成量は次式に示すように $\mathrm{SO}_{3}$ 量に よって決定される。さらにセメント中の $\mathrm{SO}_{3}$ 量はJIS

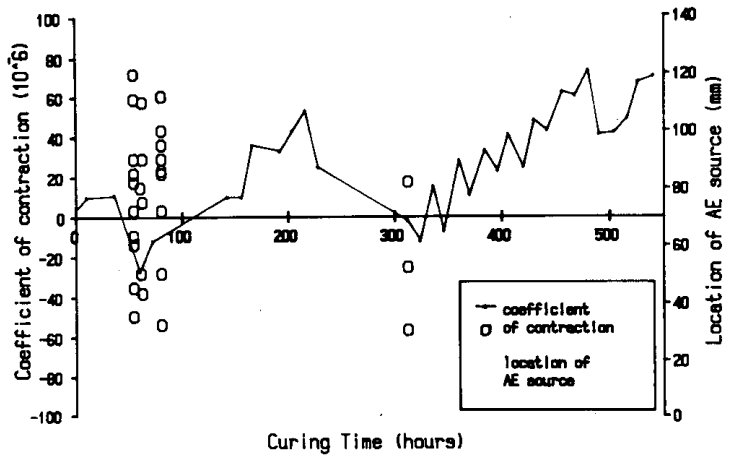

Fig.6(b) Curing Tim-Coefficient of contraction, Location of AE source (notched specimen: A 2) 
R 5210 によって 3 \% 以下（普通ポルトランドセメント） と規定されている。

$$
\begin{array}{r}
\mathrm{C}_{3} \mathrm{~A}+3\left(\mathrm{CaSO}_{4} \cdot 2 \mathrm{H}_{2} \mathrm{O}\right)+26 \mathrm{H}_{2} \mathrm{O} \\
\rightarrow \mathrm{C}_{3} \mathrm{~A} \cdot \mathrm{CaSO}_{4} \cdot 32 \mathrm{H}_{2} \mathrm{O} \cdots \cdots \cdots \cdots \cdots \cdots \cdots
\end{array}
$$

$\mathrm{SO}_{3}$ 量による彭張の割合は，収縮指数式*4によって概算 可能であり, $\mathrm{SO}_{3} 1 \%$ 増は収縮率の約 $10 \%$ 低下につな がる。よって，最大 $3 \%$ 混入時においても収縮量は 2 $3 \times 10^{-4}$ しかも低下しない。さらにエトリンガイトの結 合水は材令と共に減少し，最終的には $\mathrm{C}_{3} \mathrm{~A} . \mathrm{mH}_{2} \mathrm{O}(\mathrm{m}$ ○6）となるため，長期材令において膨張は停止すると 考えられる。

一方，次式に示すように $\mathrm{C}_{3} \mathrm{~S}$ および $\mathrm{C}_{2} \mathrm{~S}$ の水和反応 に際しては，CSH 系化合物と共に多量の消石灰が生成 される。

$$
\begin{aligned}
& \mathrm{C}_{3} \mathrm{~S}+(\mathbf{n}+2) \mathrm{H}_{2} \mathrm{O} \rightarrow \mathrm{CSnH}_{2} \mathrm{O}+2 \mathrm{Ca}(\mathrm{OH})_{2} \cdots \\
& \mathrm{C}_{2} \mathrm{~S}+(\mathbf{n}+1) \mathrm{H}_{2} \mathrm{O} \rightarrow \mathrm{CSnH}_{2} \mathrm{O}+\mathrm{Ca}(\mathrm{OH})_{2} \cdots
\end{aligned}
$$

消石灰は CSH 系化合物ならびに末反応セメントクリン カ一と共に一体構造を形成する。しかし $\mathrm{C}_{3} \mathrm{~S}$ の水和は 4 週以内にほぼ完了するが, $\mathrm{C}_{2} \mathrm{~S}$ の水和は $\mathrm{C}_{3} \mathrm{~S}$ に比べ

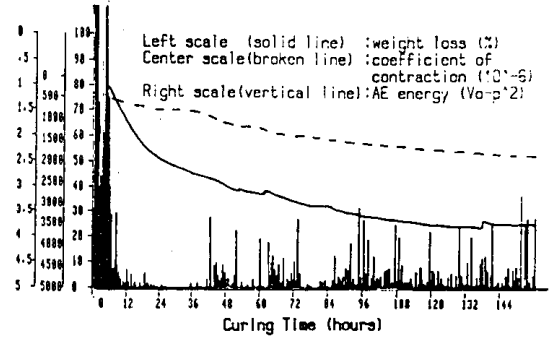

Fig. 7 Behavior of drying Shrinkage (cement paste, W/C = $40 \%$ )
相当遅れて始まり，その継続も著しく長い。さらに $\mathrm{CaO}$ 量については中庸熱ポルトランドセメントを除い ては明確な JIS 規定がないため，最近のセメントは徐々 にではあるが $\mathrm{CaO}$ 量が増加している傾向にある。以上 から,若材令において一体構造化したマトリックス部は, $\mathrm{C}_{2} \mathrm{~S}$ の遅れ水和によって膨張を開始し, 以後材令の経 過と共に膨張亀裂が断続的に発生すると推察される。

よって，従来から良質な養生方法として考えられてい た水中養生も, 養生材令によっては膨張亀裂発生の原因 ともなる。

2 恒温養生中におけるセメント系材料の乾燥収縮挙 動および $\mathrm{AE}$ 発生挙動

Fig. 7 13に恒温養生におけるセメントペーストおよ びセメントモルタルの重量変化率, 長さ変化率および $\mathrm{AE}$ エネルギーを経時変化で示した。重量変化率は一般 に供試体含水量に比例し, 図に示された実験結果と対応 している。さらに養生初期における重量変化速度（重量 変化率／経過時間）についても W/C との対応関係が明 確に認められる。なお, 川砂モルタルの重量変化速度が 標準砂モルタルに比べ速くなるのは, 表乾比重が約 0.1 小さく組織的にポーラスであるためと考える。モルタル の長さ変化率は一般に $12 \sim 15 \times 10^{-4}$ であるが, 本実験 では $\mathrm{S}: \mathrm{C}=2: 1$, 相対湿度=約 $45 \%$ に設定したため にいずれの水準においても高い値を示した。また，長さ 変化率は一般に重量変化率と対応関係にあるとされてい るが，本実験では明確な傾向を見いだすことはできな かった。

$\mathrm{AE}$ 発生挙動について注目した場合, 恒温養生開始直

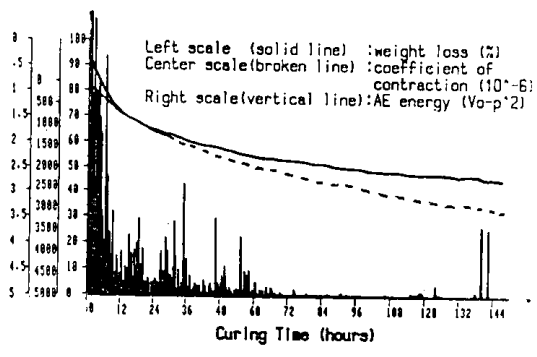

Fig. 8 Behavior of drying Shrinkage (cement mortar using standard sand, $\mathrm{W} / \mathrm{C}=40 \%$ )

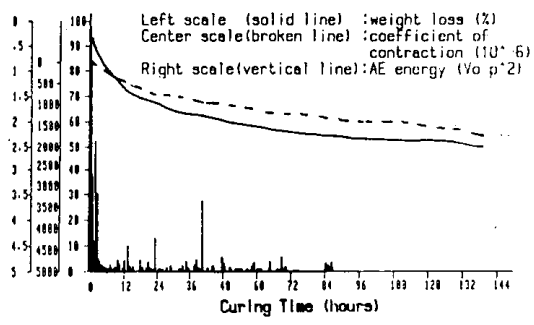

Fig. 11 Behavior of drying Shrinkage (cement mortar using river sand, $\mathrm{W} / \mathrm{C}=40 \%)$

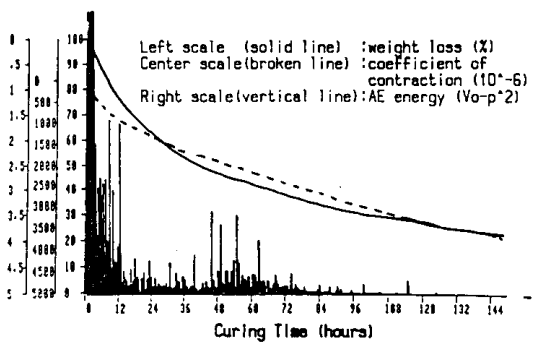

Fig. 9 Behavior of drying Shrinkage (cement mortar using standard sand, $\mathrm{W} / \mathrm{C}=50 \%$ )

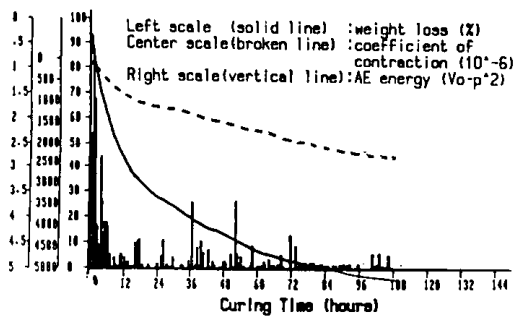

Fig. 12 Behavior of drying Shrinkage (cement mortar using river sand, $\mathrm{W} / \mathrm{C}=50 \%)$

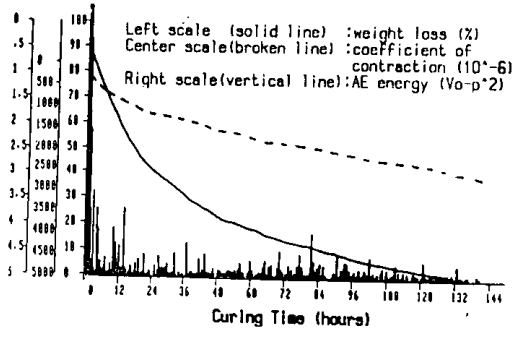

Fig. 10 Behavior of drying Shrinkage (cement mortar using standard sand, $\mathrm{W} / \mathrm{C}=60 \%$ )

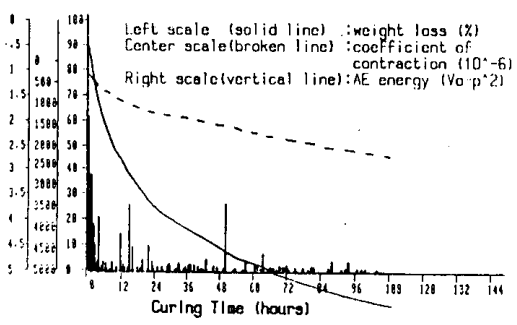

Fig. 13 Behavior of drying Shrinkage (cement mortar using river sand, $\mathrm{W} / \mathrm{C}=60 \%$ ) 
後より, 標準砂モルタルで約 3 時間, 川砂モルタルで約 30 分，セメントペーストで約 6 時間の間 $20 V_{0-p^{2}} / \mathrm{min}$ 以上の $\mathrm{AE}$ 発生が認められる。セメント系材料の $\mathrm{AE}$ 波が連続型ではなく突発型のものであることから，この 現象は明らかに収縮亀裂の発生を示しているものと考え る。さらに $\mathrm{AE}$ の連続発生時間に注目した場合, 七メ ントモルタルの場合, 恒温養生初期に急激な $\mathrm{AE}$ 発生 が認められるものの, 材令と共にしだいに隇少し, 約 100 時間以降に発生する $\mathrm{AE}$ は極めて少なくなる。一方, セメントペーストの場合養生初期の急激な発生が一旦停 止した後, 約 40 時間目以降常時 $5 \sim 10 V_{0-\rho^{2}} / \mathrm{min}$ 程度 の $\mathrm{AE}$ 発生が続く。本実験では 156 時間で測定を終了 したが，セメントペーストにおいては長時間この傾向が 続くものと推察される。

なお，標準砂モルタルが川砂モルタルに比べ多数の $\mathrm{AE}$ を発生する原因は以下の 2 点が考えられる。

1）マトリックス部に比へ弾性率の高い骨材の周辺部 に内部応力が集中するため, 微視亀裂の大多数は骨材 とマトリックス部の界面で発生し，かつこの界面の面 積と微視亀裂数はなんらかの比例関係にある。

2）川砂に対し標準砂の平均粒径は約 1/4 であること から，標準砂 1 個当たりの表面積は川砂の約 0.0625 倍, 単位容積当たりにしめる標準砂モルタル中の骨材 数は川砂モルタルの約 64 倍である。したがって, 単 位容積当たりの標準砂表面積の総和は川砂の約 4 倍に なり，マトリックス部と骨材との界面総面積は標準砂 モルタルの方が川砂モルタルよりも大きくなる。

V. まとめ

水中養生においてもセメント系材料の内部組織に多数 の微視亀裂が発生することは恒温養生時と同様 $\mathrm{AE}$ 発 生挙動より明らかである。水中養生時の長さ変化率は膨 張と収縮が繰り返され，徐々に膨張の方向に進む。しか し微視亀裂は長さ変化率に伴って常時発生するのではな く，膨張または収縮の変化速度となんらかの関係がある と推察される。

モルタルとペーストの乾燥収縮亀裂発生挙動の差は骨 材の混入が原因であり，さらに骨材粒径が微視亀裂の発 生量増減にもつながることは明らかである。これらはい ずれもマトリックスと骨材の弾性率の差によるもので, 内部応力が弾性率の高い骨材周辺に集中するためであ る。以下に本報の結果をまとめる。

1）破壊勒性試験時だけでなく, 養生中の微視破壊を

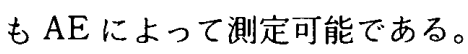

2）切り欠けの有無による微視亀裂発生挙動の差は認 められない。

3) 水中養生時, 膨張および収縮の変化率が急激に変 化する場合, 長さ変化率が極めて小さくとも, 微視亀 裂の発生する確率は高まる。
4) セメントモルタルの乾燥収縮亀裂 (微視亀裂) は, 養生開始直後多数発生するものの, 約 5 時間ほどで停 止し, 以後の発生は極めて少ない。

5）セメントペーストの乾燥収縮亀裂 (微視亀裂) は, 養生開始直後の急激な発生が停止した後も時間をおい て周期的に発生する。

6）骨材粒径の小さいモルタルの方が乾燥収縮亀裂発 生量は多くなる。

7）セメントペーストく標準砂モルタルく川砂モルタ ルの順で $\mathrm{AE}$ イベントエネルギーが高くなる。これ により同じ乾燥収縮亀裂でも, 骨材の混入, 骨材粒径 の増大により，亀裂面積が増大することが把握できる。 本研究（本報および第 2 報）は養生中に発生する微視 亀裂が，セメント系材料の力学的特性に対しだのような 影響をおよぼすかを明らかにすることを目的としたもの で, 本報はこの内養生中の微視亀裂挙動に関して述べた。 したがって, 本研究では養生中および養生後の関係を簡 潔にするため, 湿度, 温度および材令等の養生条件を実 験要因に加えなかった。しかし，本研究終了後はさらに 養生条件を変えた場合の, 微視亀裂発生挙動および破壊 挙動との関係を明らかにしてゆきたいと考えている。

\section{謝 辞}

この研究期間中, 高橋和雄氏, 古賀一八氏（東京理科 大学)ならびに寺村敏史氏 (小野田セメント中央研究所) に有益な助言を頂きました。心から感謝致します。

\section{参考文献}

1）浜田 稔, 重倉祐光, 藤松 進, ほか：コンクリートの 収縮キレツ対策, 建材特定問題講習会 建材試験セン タ- 1968

2）重倉祐光, 松茂二郎, 松田応作, 関宮博史：コンクリー 卜乾燥収縮亀裂防止に関する研究，日本建築学会論文報 告集 V.107 1965, 1

3）重倉祐光,ほか：コンクリート乾燥収縮亀裂防止に関す る研究 その2, 日本建築学会論文報告集 V. 128 1966,10

4）藤松 進：二水石育混和によるコンクリートのきれつ防 止, 日本建築学会論文報告集 V.92 1963,11

5）鈴木計夫, 大野義照, 太田 寛: 収縮拘束試験と実構造 物のひびわれ発生予測, 日本建築学会近畿支部研究報告 集 1982,7

6）永松静也：モルタル・コンクリートの乾燥収縮歪みおよ びそれに起因する内部応力について，セメント技術年報 V. 261977 p. 293-297

7）永松静也, 竹田吉紹：乾燥にともなうコンクリートの各 種強度変化について, セメント技術年報 V. 361982 p. 271-274

8) Rusch and Jungwirth, 百島祐信訳：コンクリート構造 物のクリープと乾燥収縮, 鹿島出版会

9）尾上守夫,ほか：アコースティック・エミッションの基 礎と応用, コロナ社 1972

10）和泉正哲, 三橋博三：コンクリートの破壊研究への $\mathrm{AE}$ 
の応用その1, 日本建築学会東北支部研究発表会 p. 197-200 1982, 2

11）和泉正哲, 野村希晶, 栗田 哲: コンクリートの破壊研 究への $\mathrm{AE}$ の応用 その 2 , 日本建築学会東北支部研究 発表会 p. 201-204 1982,2

12）横道英雄, ほか：セメントペーストの破壊機構について の一考察, セメント技術年報 V.24 1975

13）横道英雄, 池田郁雄, 松岡健一：コンクリートにひびわ れが生ずるときの弾性波の伝達現象について, セメント 技術年報 V. 181964

14）横道英雄, 松岡健一, 高田宣之：コンクリートのひびわ れ発見に関する 2,3 の実験, セメント技術年報 V.19 1966

15）小阪義夫, 山田和夫：コンクリートの累積損傷と $\mathrm{AE}$ 特 性との関係，七メント技術大会講演要旨 V. 36 p. 229-232 1982

16）小阪義夫, 山田和夫, 谷川恭雄 : コンクリートのアコー スティック・エミッション特性と破壊挙動に関する基礎 的研究, 日本建築学会構造系論文報告集 V.358 1985, 12

17）三橋博三, 和泉正哲：コンクリートの破壊勒性試験に関 する一考察, 日本建築学会東北支部研究発表会 p. 253-256 1982,11

18）高橋秀明, 新妻弘明：弾塑性破壊勒性試験における $\mathrm{AE}$
計測法と信号処理法, 非破壊検査 V. 30-10 p. 886-889 1981

19）梘山興一, 寺村敏史：破壊勒性試験法の開発と軽量コン クリートの応用, 非破壊検查 V. 30-11 p. 865-867 1981

20）岸 輝雄, 栗林一彦, 大野一生: $\mathrm{AE}$ 源波形解析手法の 確立と破壊の動的挙動解明への適用, 非破壊検查 V. 30-11 1981

21）新妻弘明, 高橋秀明, 中鉢憲賢 : 周波数解析にもとづく $\mathrm{AE}$ 発生パターンの分類と微視破壊過程, 非破壊検査 V. $30-111981$

22）高坪純治, 吉田憲一：AE 源波形解析（その手法と有効 性)，中国工業技術試験所報告 V.17 1982

23）高橋秀明, 新妻弘明, 鈴木正彦, 森、康彦: 破壊勒性試 験における $\mathrm{AE}$ 発生パターンの分類とその評価, 非破壊 検査 V.30-11 1981

24）和泉正哲, 三橋博三, 野村希晶：AEによるコンクリー 卜材料の乾燥収縮割れならびに破壊勒性の評価, 非破壊 検査 V.006-38 1982

25）日本機械学会基準（弾塑性破壊勒性 JIC 試験方法） JSME S 001 1981, 10

26）重倉祐光：コンクリートブロック目地の付着機構とひび 割れ発生ならびに対策について，小野田研究報告 V.13 1961

\section{SYNOPSIS}

UDC : $691.53: 691.32: 693.547$

\section{STUDY ON THE CRACKING BEHAVIOR OF CEMENT MORTAR UNDER WATER CURING AND STANDARD CURING}

Study of the cracking behavior and fracture behavior of cement material using AE (Acoustic Emission) Vol. 1

by HIROYUKI TANANO, Dr. YUKO SIGEKURA, Dr. KOUICHI TSUKIYAMA,

Members of A. I. J.

We measured the weight loss, the coefficient of contraction and cracking behavior of cement mortor and cement paste by $\mathrm{AE}$ technique. The experimental results are summarized as follows. 1) The microscopic fracture is occured, when suddenly changed rate of shrinkage and expansion increase. 2) The shrinkage crack of cement mortar is occured from immediately after standard curing to about 5 hours. But from about 5 hours, it is no occured. 3) The shrinkage crack of cement paste is occured from immediately after standard curing to about 3 hours. After that, it's occured periodically. 4) The relation of AE event energy and amount of shrinkage crack is expressed as follows. Cement paste $<$ Cement mortar using standard sand $<$ Cement mortar using River sand. 